\title{
STUDY ON SOME AEROBIC BACTERIAL SPECIES IN ORNAMENTAL FISH
}

\author{
AYA GALAL SAAD EL-DEEN ${ }^{*}$ and MOHAMMED RAWWAY ${ }^{* *}$ \\ * Animal Health Research Institute, Assiut Laboratory. \\ ** Botany and Microbiology Department, Faculty of science, Al-Azhar University- Assiut branch, Assiut, Egypt. \\ Email: aya9galal@gmail.com
}

\section{ABSTRACT}

Received at: 4/9/2014

Accepted: 23/11/2014

\begin{abstract}
This study was performed to detect the presence of some microbes which cause diseases in ornamental fish, pathogenesis of Aeromonas hydrophila to goldfish (Carrassius auratus), in addition to detect the more sensitive antibiotics for these microbes also, with trials for treatment of the most prevailing bacteria. One hundred apparently infected ornamental fish namely fantail, goldfish (Carassius auratus auratus) Black molly (Poecillia latipinna) and koi carp (cyprinus carpio) was randomly collected from private ornamental fish shops. The clinical examinations of these naturally infected fish were recorded. Standard microbiological methods were used for isolation and characterization of bacteria associated with diseased fish. The results revealed that the prevalence of bacterial diseases was $38 \%$ among the examined fish. The isolated and identified bacteria were Aeromonas hydrophila in a percentage of $23.75 \%$, Pseudomonas aeruginosa in a percentage of $22.5 \%$ and Enterobacteriaceae in a percentage of $53.75 \%$. Pathogencity of selected bacterial isolate belonged to A. hydrophila was done through experimental challenge via immersion route. Clinical signs and postmortem lesions were recorded; nearly the same clinopathological picture which noticed in naturally infected fish. The therapeutic efficacy of Enrofloxacin (2mg/L with 24 hours between dosing) was evaluated in the treatment of artificial infection with A. hydrophila in goldfish. Mortalities of fish were reduced by administered daily as compared to control group. The isolation frequencies of $A$. hydrophila in each group during and after medication indicated that Enrofloxacin (Mortril) seemed to give good protection against A. hydrophila in goldfish. Antibiotic sensitivity tests revealed that $A$. hydrophila were sensitive to sulphatrimethoprim, ciprofloxacin, gentamicine, florfenicol, enrofloxacin and norfloxacin. Pseudomonase sp. were sensitive to oxytetracycline, gentamicine and ciprofloxacin, while Enterobacteriaceae were sensitive to gentamicine and ciprofloxacin.
\end{abstract}

Key words: Ornamental fish-Aeromonas Spp. - Enterobacteriaceae-Pseudomonas Spp.

\section{INTRODUCTION}

Koi (Cyprinus carpio) and fancy goldfish (Carassius auratus) are popular and intensively reared ornamental fishes for pets, display and show. Intensive rearing of these fishes usually results in high population densities, which subsequently may result in a high occurrence of disease (Siegel et al., 2004). As it seems that the ornamental fish shops began to spread nowadays, moreover the aquaria containing ornamental fish are often found in restaurant, homes, medical and dental office and even in hospitals. The presence of potentially pathogenic bacteria in these aquaria may represent a threat to public health. Also fish disease is a major risk factor in commercial aquaculture with millions of dollars lost annually.
Bacterial disease is enormously common in ornamental fish and one of the most important diseases in ornamental fishes and a significant cause of high fish morbidity and mortality rates (Barker, 2001). Different pathogenic, especially, gram negative bacteria has been reported to be isolated from naturally-infected fish. Many stress factors could contribute to bacterial infection in ornamental fish, namely, poor water quality, crowding, transportation and inadequate nutrition (Musa et al., 2008). Clinical signs of bacterial disease may be peracute (mortality without gross evidence of disease), acute, or chronic.

Aeromonas hydrophila has become the most important pathogenic bacteria for Cyprinoid fish and 
may result in a syndrome called motile aeromonad septicemia (MAS). Common clinical signs include cutaneous hemorrhages and ulcers that can be deep through the dermis to connective tissue and muscle, visceral hemorrhages, edema, dropsy or ascites, and exophthalmia (Palmeiro and Roberts 2009).

Antibiotics have been used for treatment and prevention of bacterial diseases, but the success of treatment depends on antibiotic susceptibility of etiologic bacteria (Yanong, 2006). Resistance of Aeromonas spp. to commonly used antibiotics is an emerging problem in the ornamental fish (RoweMagnus et al., 2002). Bacterial resistance is an important issue that needs to be considered when choosing an appropriate antibiotic.

The objectives of the present study are to isolate and identify the most predominant bacterial pathogens which cause diseases in ornamental fish. The pathogenicity, sensitivity of these pathogens and trail for treatment of the most prevailing bacteria are also investigated.

\section{MATERIALS AND METHODS}

1-Fish:

1-1 naturally infected fish:

A total number of one hundred apparently infected ornamental fish of different species namely fantail, gold fish (Carassius auratus auratus) Black molly (Poecillia latipinna) and koi carp (cyprinus carpio) in a body weight ranged from $10-25 \mathrm{~g}$ were collected from pet shops of different States in Assiut governorate. Fish were transported alive or freshly dead as soon as possible to the Aquatic Animals Diagnostic Laboratory, Faculty of Veterinary Medicine, Assiut University, where All fish were subjected to full clinical, post-mortem and bacteriological examinations (Melba et al., 2001).

\section{1-2 Experimental fish:}

A total number of 100 apparently healthy goldfish (family Cyprinidae) purchased from a local pet shops in Assiut governorate (as model of ornamental fish). They were $15-20 \mathrm{~g}$ in weight and $9-14 \mathrm{~cm}$ in total length. The fish were maintained in aerated glass aquaria and acclimatized for two weeks before infectivity testing. The glass aquaria were supplied with chlorine-free tap water, aeration, heater $\left(23 \pm 2^{\circ} \mathrm{C}\right)$ and filter. During the acclimatization period, these fish were fed daily with commercial feed at $3-5 \%$ body weight. The fish were examined to ensure that they were disease-free prior to use in the trial.

\section{Aquaria:}

Glass aquaria $(60 \times 30 \times 90)$ were used for holding and performing the experimental infection of fish. They were supplied with continuous aeration, filtration and heating. They were provided with chlorine- free tap water according to the methods adapted by Innes (1966). A sponge filter was fixed for clarifying water from fish waste and food residues with oxygen supply.

\section{2- Bacterial isolation and identification:}

Samples were taken under aseptic precautions from liver and kidney of collected fish. Samples of liver and kidney were bacteriologically examined by inoculation on brain heart infusion agar (BHI) (Lab$\mathrm{M})$, selective pseudomonas isolated agar (Lab M) and bile salt brilliant green agar (aeromonas agar (Lab M), then incubated at $28^{\circ} \mathrm{C}$ for 24 hours. The selected isolates were identified based on cultural, morphological, and biochemical characters according to (Austin and Austin, 2007).

\section{3- Pathogenicity of Aeromonas hydrophila: 3- 1Bacterial strain:}

Bacterial strains were kept in BHI broth with $15 \%$ glycerol (El-Gomhurrhia, Cairo, Egypt) at $-20^{\circ} \mathrm{C}$. The A. hydrophilla strain was passed three times in fantail fish through intraperitoneal injection before using for experimental challenge.

\section{3- 2Bacterial challenge suspension and counts:}

Colony forming units (cfu) counts in bacterial suspensions were determined using spectrophotometry optical density values at wavelength of $600 \mathrm{~nm}$ and standard-plate-count method with ten-fold serial dilution (Elkamel and Thune 2003).

\section{3-3 Experimental infection:}

In a preliminary challenge, four groups of fish were subjected to infection through immersion in well identified $A$. hydrophila at concentration $1 \times 10^{5}$, $1 \times 10^{6}, 1 \times 10^{7}, 1 \times 10^{8} \mathrm{cfu} / \mathrm{ml}$ for 30 minutes in $30 \mathrm{~L}$ proved to be lethal within 7 day to all goldfish. Thus, lower concentrations of the bacterial suspensions were used for experimental challenge.

Experimental infection trails were conducted to test pathogencity of A. hydrophila to goldfish. A total number of 30 apparently healthy fantail were divided in 2 groups, each group in 3 glass aquaria. The fish in the first group was negative control, while the fish in other groups were infected through immersion for 30 minutes in well identified $A$. hydrophila at concentration $1 \times 10^{7} \mathrm{cfu} / \mathrm{ml}$ suspension of A.hydrophila for 30 minutes in 30 L. All experimentally infected fish were observed daily for any clinical signs and mortalities were recorded. Reisolation of $A$. hydrophila was made from all experimental fish. The whole experiment was repeated three times.

\section{4- Antibiotic sensitivity test:}

The sensitivity of bacterial isolates to different antibiotics was carried out using the disc diffusion technique and the following antibiotics Oxytetracycline, $30 \mu \mathrm{g}$, Sulphatrimethoprim, $25 \mu \mathrm{g}$, 
Gentamicine, $10 \mu \mathrm{g}$, Lincomycin, $2 \mu \mathrm{g}$, Tobramycin, $10 \mu \mathrm{g}$, Neomycin, $30 \mu \mathrm{g}$, Amoxyvft, $25 \mu \mathrm{g}$, Ciprofloxacin, $5 \mu \mathrm{g}$, Florfenicol, $30 \mu \mathrm{g}$, Enrofloxacin, $5 \mu \mathrm{g}$ and Norfloxacin, $10 \mu \mathrm{g}$ are used. The interpretations of zones were estimated according to the limits given by Carter and Cole, (1990).

\section{5- Treatment test:}

A total number of 45 clinically healthy goldfish were used for the trials of treatment. They were divided into three equal groups, each of 15 fish. Two groups were experimentally infected through immersion in 1 X $10^{7} \mathrm{cfu} / \mathrm{ml}$, suspension of A. hydrophila for 30 minutes in $30 \mathrm{~L}$ water, while the other group remained unchallenged as control. One of these two experimentally infected group was treated after one day for five consecutive days with Enrofloxacin $2 \mathrm{mg} / \mathrm{l}$ with 24 hours between dosing, and a $50 \%$ water change between daily treatments. (mortril $250 \mathrm{ml}=$ introfloxacin basic). Fish were placed under observation and the mortalities among treated, untreated and control groups were recorded for 30 days. Fish in a dying state or just after death were sampled for re-isolation of micro-organism. Bacteriological examination was also carried out on the surviving fish for re-isolation of micro- organism after completion of medication during experimental period. The whole experiment was repeated three times.

\section{RESULTS}

\section{Clinical examination of Naturally Infected Ornamental Fish:}

In this study, the clinical examinations of randomly collected ornamental fish were fin and tail rot, excessive mucous secretion. Also detachment of the scales, exophthalmia and body deformity with external hemorrhages. Gills were congested in some fish, while in other fish appear to be pale with accumulation of excessive amount of mucus. Necropsy findings of naturally infected ornamental fish exhibited bloody serious fluid in the abdominal cavity .Liver was congested and friable, while kidney was congested and enlarged.

\section{Bacterial isolates from diseased ornamental fish:}

The bacteriological examination revealed the isolation of 80 different pathogenic bacterial isolates. The clinical examination of naturally infected ornamental fish revealed that the prevalence of diseases caused by bacterial agents represent $38 \%$ of the examined cases (Table, 1). Out of 100 ornamental fish subjected to the above microbiological studies, Aeromonas hydrophila were isolated from 16 fish, Pseudomonas aeruginosa from 12 fish and Enterobacteriaceae from 37 fish. The frequent distributions of the recovered isolates are presented in (Table, 2). Major dominant micro biota such as Aeromonas sp, Pseudomonas sp, and Enterobacteriaceae were isolated from the different samples such as liver and kidney of the infected ornamental fish. Among the dominant micro biota Enterobacteriacae, A. hydrophila and Pseudomonas aeruginosa were isolated in percentage $53.75 \%$, $23.75 \%$ and $22.5 \%$ respectively.

A. hydrophila proved to be motile, G-ve, short bacilli. It appeared creamy color colonies, 1-2 $\mathrm{mm}$ in diameter on BHI agar. While appeared whitish colonies with change color of media from red to yellow on bile salt brilliant green agar. It was identified according to its morphological, culture and biochemical characters and shown in (Table, 3 ).

$P$. aeruginosa were isolated on non-selective media (BHI agar) and appeared as circulated, convex, entire edge, glistening creamy colonies and 1-2 $\mathrm{mm}$ in diameter. While on pseudomonas isolated agar developed as yellowish green colonies with rounded edges and about 1-2 $\mathrm{mm}$ in diameter. Biochemical character of $P$. aeruginosa are shown in (Table, 4).

Enterobacteriaceae are gram-negative bacteria. Proteus were isolated on BHI agar and appeared thin, colorless, transparent, swarming colonies, while E. coli colonies were small, smooth, moist, with a shiny surface, also Edwardsiella tarda colonies were small gray, round transparent. Results of the biochemical characters and enzymes activities of isolated bacteria are shown in (Table, 5).

\section{Experimental infection:}

Pathogencity of selected bacterial isolate belonged to A. hydrophila was done through experimental challenge via immersion route. Clinical signs associated with bacterial infection were exophthalmia, haemorrhage on body surface and tail fin (2 cases) (Fig,1). Scale detachment and ulcer formation on the body surface ( 2 cases) (Fig,2). Gills and liver were congested. Congested, enlarged kidneys were seen in 7 cases. Ascitis and bloody serious fluid in the abdomen cavity were observed in2 cases .Bloody exudates in the intestine were detected in 3 cases (Fig, 3). White nodule easily detachment on skin surface with haemorrhage at its base ( 1 case). The average mortality was $26.66 \%$. Re- isolation of the bacteria in pure culture was done from freshly dead and moribund fish. There was no mortality or clinical signs of infection in both of the control groups.

Re-isolation of all inoculated bacterial isolate was obtained from dead and scarified fish. Moreover, the results of the culture and biochemical characteristics of the re-isolated bacterial isolate revealed the same morpho-chemical characteristics of the inoculated bacterial isolate. 


\section{Antibiogram sensitivity:}

The results of in vitro antibiotic sensitivity test on randomly isolates isolated from naturally infected fish were shown in (Table, 6).

\section{Treatment:}

The therapeutic efficacy of Enrofloxacin was evaluated in the treatment of artificial infection with A. hydrophila in goldfish by the dead fish $\%$ and the re-isolation frequency of the bacteria from fish during experimental period. Mortalities of fish were reduced by administered daily of Enrofloxacin as compared to control group. The final cumulative mortalities were $13.33 \%$, but $26.66 \%$ in the control group while $0 \%$ in the sham control group. A. hydrophila can be isolated from control group throughout the test period whereas; the bacterium was not detected in some fish treated with Enrofloxacin after completion of medication.

Small haemorrhagic skin lesions, ulceration, ascites, loss brightness, congested gills bloody exudates in the peritoneum, caseous materials covering gas bladder, and enlarged congested kidney were seen in some cases in group 2, while these lesions and symptoms were minimized in $1^{\text {st }}$ group and sporadically seen (un-treated group).

Table 1: The prevalence of bacterial infections in naturally infected ornamental fish:

$\begin{array}{cccc}\begin{array}{c}\text { Prevalence of } \\ \text { bacterial infections }\end{array} & \begin{array}{c}\text { Total NO. of } \\ \text { examined fish }\end{array} & \begin{array}{c}\text { No. of naturally } \\ \text { infected fish }\end{array} & \text { Percentage } \\ \end{array}$

$100 \quad 38$

Table 2: Pathogenic bacterial species isolated from fish:

\begin{tabular}{lcc}
\hline Bacterial pathogens & No. of isolates & Percent $\%$ \\
\hline Enterobacteriaceae & 43 & $53.75 \%$ \\
\hline Aeromonas hydrophila & 19 & $23.75 \%$ \\
\hline Pseudomonas aeruginosa & 18 & $22.5 \%$ \\
\hline Total number & 80 & $100 \%$ \\
\hline
\end{tabular}

Table 3: Morphological, cultural and biochemical characters of the isolated Aeromonas hydrophila

\begin{tabular}{cc}
\hline Tests & Aeromonas hydrophila \\
\hline No. & 19 \\
\hline Gram-stain & -ve \\
\hline Motility & + ve \\
\hline Catalase & + \\
\hline Cytochrom oxidase & + \\
\hline Indole & + \\
\hline H2S & - \\
\hline Methyl red & + \\
\hline Vogus-proskauer & - \\
\hline O/F & $+/+$ \\
\hline Growth on 0\% Nacl & + \\
\hline Growth on3\% Nacl & - \\
\hline Glucose & + \\
\hline Lactose & - \\
\hline Sucrose & + \\
\hline Maltose & + \\
\hline
\end{tabular}


Assiut Vet. Med. J. Vol. 60 No. 143 October 2014

Table 4: Morphological, cultural and biochemical characters of the isolated Pseudomonas aeruginosa

\begin{tabular}{|c|c|}
\hline Tests & Pseudomonas aeruginosa \\
\hline No. & 18 \\
\hline Gram-stain & G-ve \\
\hline Motility & + \\
\hline Catalase & + \\
\hline Cytochrom oxidase & + \\
\hline Indole & - \\
\hline $\mathrm{H} 2 \mathrm{~S}$ & - \\
\hline Methyl red & - \\
\hline Vogus-proskauer & - \\
\hline Citrate & - \\
\hline $\mathrm{O} / \mathrm{F}$ & $-1-$ \\
\hline Growth on $0 \% \mathrm{Nacl}$ & + \\
\hline Growth on3\% Nacl & + \\
\hline Urease & + \\
\hline Gelatin lequification & + \\
\hline Mannitol & + \\
\hline Glucose & + \\
\hline Lactose & - \\
\hline Sucrose & - \\
\hline Maltose & - \\
\hline
\end{tabular}

Table 5: Morphological, cultural and biochemical characters of the isolated Enterobacteriacea

\begin{tabular}{|c|c|c|c|c|c|c|}
\hline Test & $\begin{array}{l}\text { Proteus } \\
\text { vulgaris }\end{array}$ & $\begin{array}{l}\text { Proteus } \\
\text { mirbalis }\end{array}$ & Klebsiella & $\begin{array}{c}\text { Edwardsiella } \\
\text { tarda }\end{array}$ & Ecoli & Shigella \\
\hline No. & 8 & 17 & 4 & 2 & 2 & 10 \\
\hline Gram-stain & Gram-ve & Gram-ve & Gram-ve & Gram-ve & Gram-ve & Gram-ve \\
\hline Motility & + & + & + & + & + & + \\
\hline atalase & + & + & + & + & + & + \\
\hline $\begin{array}{l}\text { Cytochrom } \\
\text { oxidase }\end{array}$ & - & - & - & - & - & - \\
\hline Indole & + & - & - & + & + & - \\
\hline $\mathrm{H} 2 \mathrm{~S}$ & + & + & - & + & - & - \\
\hline Methyl red & + & + & + & + & + & + \\
\hline $\begin{array}{l}\text { Vogus- } \\
\text { proskauer }\end{array}$ & - & - & - & - & - & - \\
\hline $\begin{array}{l}\text { Simmon } \\
\text { citrate }\end{array}$ & - & - & + & - & - & - \\
\hline Urease & + & + & - & - & - & - \\
\hline Glucose & + & + & + & + & + & + \\
\hline Lactose & - & - & + & - & - & - \\
\hline Sucrose & + & - & - & - & + & - \\
\hline Maltose & + & - & + & + & + & - \\
\hline
\end{tabular}


Assiut Vet. Med. J. Vol. 60 No. 143 October 2014

Table 6: Antibacterial sensitivity test of the isolated bacteria:

\begin{tabular}{lcccc}
\hline Antimicrobial agent & Disc cnc. & $\begin{array}{c}\text { Enterobacteri } \\
\text { acea }\end{array}$ & P. aeruginosa & A. hydrophila \\
\hline Oxytetracycline (T) & $30 \mu \mathrm{g}$ & $\mathrm{R}$ & $\mathrm{S}$ & $\mathrm{R}$ \\
\hline Sulphatrimethoprim (SXT) & $25 \mu \mathrm{g}$ & $\mathrm{R}$ & $\mathrm{R}$ & $\mathrm{S}$ \\
\hline Gentamicine (CN) & $10 \mu \mathrm{g}$ & $\mathrm{S}$ & $\mathrm{S}$ & $\mathrm{S}$ \\
\hline Lincomycin (L) & $2 \mu \mathrm{g}$ & $\mathrm{R}$ & $\mathrm{R}$ & $\mathrm{R}$ \\
\hline Tobramycin (TOB) & $10 \mu \mathrm{g}$ & $\mathrm{R}$ & $\mathrm{R}$ & $\mathrm{R}$ \\
\hline Neomycin (N) & $30 \mu \mathrm{g}$ & $\mathrm{R}$ & $\mathrm{I}$ & $\mathrm{I}$ \\
\hline Amoxyvft (Amox) & $25 \mu \mathrm{g}$ & $\mathrm{R}$ & $\mathrm{R}$ & $\mathrm{R}$ \\
\hline Ciprofloxacin (CIP) & $5 \mu \mathrm{g}$ & $\mathrm{S}$ & $\mathrm{S}$ & $\mathrm{S}$ \\
\hline Florfenicol ( FfC) & $30 \mu \mathrm{g}$ & & & $\mathrm{S}$ \\
\hline Enrofloxacin (ENR) & $5 \mu \mathrm{g}$ & & & $\mathrm{S}$ \\
\hline Norfloxacin (NOR) & $10 \mu \mathrm{g}$ & & & $\mathrm{S}$ \\
\hline
\end{tabular}

i.e. R: resistance

I: intermediate

$\mathrm{S}$ : sensitive

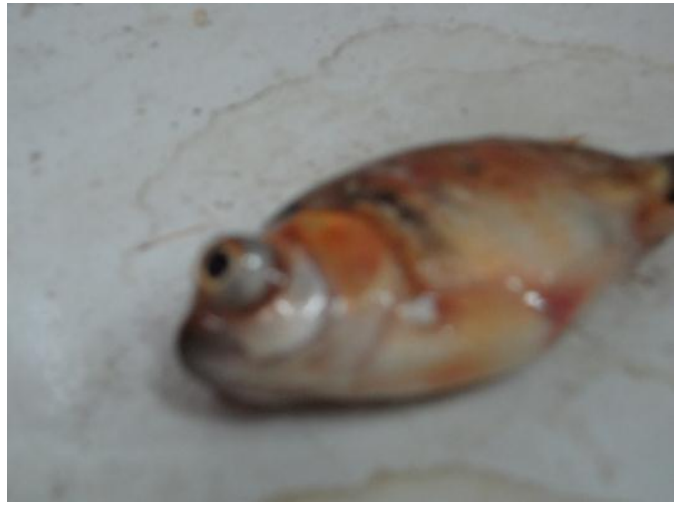

Fig. 1: Experimentally infected Goldfish (Carassius auratus) showing exophthalmia

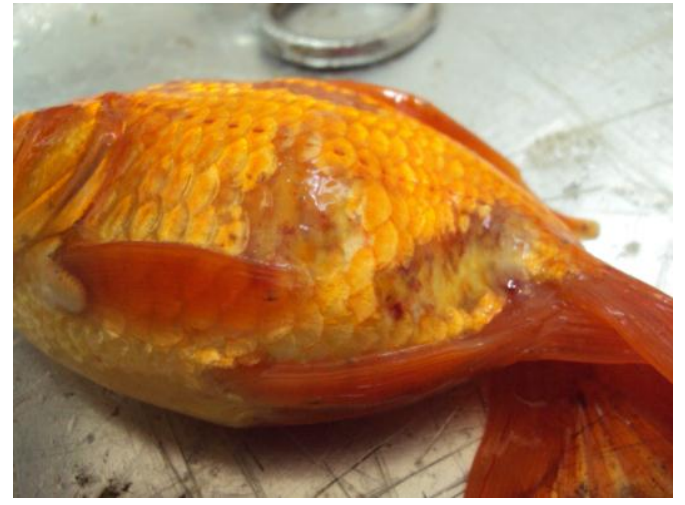

Fig. 2: Experimentally infected Goldfish (Carassius auratus) showing detachment Of scales and haemorrhagic skin

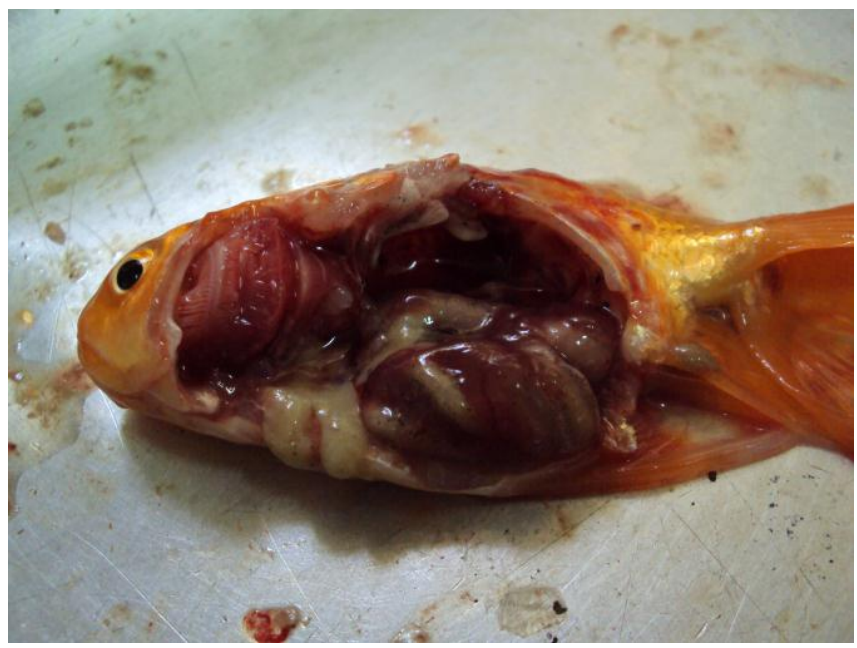

Fig 3: Experimentally infected Goldfish (Carassius auratus) Showing congested kidney, bloody exudate in the intestine and peritoneum 


\section{DISCUSSION}

A wide range of pathogens is associated with ornamental fish diseases. In this study, the clinical examination of randomly collected ornamental fishes indicated that the presence of various clinical signs including detachment of the scales, exophthalmia, body deformity and external hemorrhages. These observations supported those reported by Amlacher (1961) and Marzouk et al. (2009). However, these signs could be attributed to other infectious and/or non-infectious causes which are usually present in the aquatic environment.

The results of bacteriological examination revealed that the prevalence of bacterial infection at percentage $(38 \%)$ of total examined fish. This may be due to various stress factors namely abnormal water temperature, bad management and overcrowded (high density) which suppress immune response of fish and allowed most opportunistic bacteria to infect such fish (Austin and Austin 2007). Results of biochemical tests were similar to those reported by other investigations including Garrity, (2001) and Dias (2012).

A. hydrophila were isolated from fish suffered from diseased condition. These result are agreement with Carson and Handlinger (1988), Ahmed et al. (1990) and Khater et al. (1997). Musa et al. (2008) isolated A. hydrophila from sick freshwater ornamental fish. Dias, (2012) could isolate Aeromonas sp. From ornamental fish.

Pseudomonas aeruginosa were isolated from ornamental fish. Ahmed et al. (1990) and Fayed et al. (1997) could isolate pseudomonas from ornamental fish in Egypt. Mastan, (2013) could isolate pseudomonas sp. from goldfish (Pseudomonads namely Pseudomonas anguilliseptica, P. fluorescens, $P$. aeruginosa, and Pseudomonas sp).

Goldfish, Carrasius auratus were used as a model in the experimental infection, this may be due to goldfish, has high susceptibility to motile aeromonads and are commonly valuable for experimental animals (Citarasu et al., 2011). A. hydrophila were used in challenge experiment. This may be due to Shotts et al. (1976) also established $A$. hydrophila as a major disease problem in ornamental fish. A. hydrophila have become the most important pathogen bacteria for Cyprinoid fish (Palmeiro and Roberts 2009).

The present challenge experiment against $A$. hydrophila to the goldfish revealed that $A$. hydrophila is a pathogenic and a serious pathogen to goldfish. It caused $26.66 \%$ mortality in fish infected with $1 \times 10^{7} \mathrm{cfu} / \mathrm{ml}$. These results agree with Iqbal et al. (1999). In the experimental ornamental fish, we observed that, the mortality found in the early stage with detachment of scales, exophthalmia, ascites. These external symptoms are due to the secretions of virulent protease and haemolysis etc (Iqbal et al., 1999). Challenge fish exhibited congested liver, enlarged congested kidney and bloody serious exudates in the abdominal cavity. These results explain by Wretlind et al. (1973) who said that $A$. hydrophila produces a variety of biologically active extra cellular products (ECP), including enzymes and haemolysin compound and they expressed the virulence factors including haemolysins, proteases, cholinesterases, enterotoxins, endotoxins, and adhesins all of which contribute to the overall development of the disease in fish. Saavedra et al. (2004) reported that, the pathogenicity of $A$. hydrophila for experimentally infected goldfish may be attributed to toxins and extracellular enzymes produced by $A$. hydrophila.

Prior in vitro studies in the laboratory have shown that Aeromonas spp. isolated from ornamental fish develop resistance to common used antibiotics. These results agree with Dixon et al. (1990). A.hydrophila was subjected to biogram results indicated that the organism was resistance to oxytetracycline and intermediate to neomycin. These results disagree with Khater et al. (1997). This might indicate antibiotic misuse in aquatic animals. Novick (1981) stated that the sub therapeutic use of antibiotics in animal husbandry practice has promoted the emergence and maintenance of multiple antibiotic resistant (MAR) pathogenic bacteria. Resistance of Aeromonas spp. to commonly used antibiotics is an emerging problem in the ornamental fish. An increase in resistance levels of the genus Aeromonas, particularly to $\beta$-lactam antibiotics has been observed previously (Schmidt et al., 2000)

The antibiotic susceptibility profile to A. hydrophila revealed highly resistance to Oxytetracycline, Lincomycin, Tobramycin and Amoxyvft. On other hand A. hydrophila were sensitive to Sulphatrimethoprim, Gentamicine, Florfenicol, Enrofloxacin and Norfloxacin. The results showed that these Aeromonas spp. strains are potentially reservoirs of antibiotic resistance genes (Dias et al., 2012).

These findings raise questions, Resistance of Aeromonas spp. to commonly used antibiotics is an emerging problem in the ornamental fish.

Antibiotics of the family quinolones (norfloxacin and enrofloxacin) and gentamicin proved to be the most efficacious on $A$. hydrophila isolates. This finding is in agreement with the observation of (Hettiarachchi and Cheong 1994) also found the 
quinolone family antibiotics as the most effective antimicrobial drug on freshwater $A$. hydrophila from ornamental fish. Though the development of plasmid mediated resistant to quinolones is rare," kaser et al., 1991.

In experiment of treatment, the number of dead fish decrease during test period in comparison with untreated group. (Mortalities of fish were reduced significantly by Enrofloxacin immersion daily in comparison with control group). Furthermore the bacteria were not detected in some treated group of fish after completion of medication. So, the drug is considered to be effective against $A$. hydrophila in goldfish.

In conclusion, this investigation provides valuable information on the major aerobic bacterial species in ornamental fish in Assiut. A. hydrophila is considered as a major disease problem in ornamental fish, and choice of the most effective antimicrobials against them.

\section{REFERENCES}

Ahmed, L.S.; Ahmed, SH.M.; Ali, H.S.; Kamel, Y.Y. and EL-Allawy, T.A. (1990): Cause of mortality in aquarium fish, Angelfish (Pterophyllum scalare).Assiut Vet. Med. J. 23(46): 179-187.

Amlacher, E. (1961): Taschebuch der Fischrankherten. Gustaf Fischer Verlag Jena, pp: 286. (Cited by Jensen, 1970).

Austin, B. and Austin, D.A. (2007): Characteristics of the pathogens: Gram-negative bacteria, In Bacterial Fish Pathogens: disease of farmed and wild fish fourth edition. Springer-Praxis. Praxis Publishing Ltd., Chichester, UK.

Barker, G. (2001): Bacterial diseases. In: BSAVA manual of ornamental fish. W.H. Wildgoose (ed). Spain: British Small Animal Veterinary Association. 185-194.

Carson, J. and Handlinger, J. (1988): Virulence of the etiological agent of goldfish ulcer disease in Atlantic salmon, Salmo salar L. Journal of fish diseases.11 (6): 471-479.

Carter, G.R. and Cole, J.R. (1990): Diagnostic procedure in veterinary bacteriology and mycology. $5^{\text {th }}$ ed. Academic Press.

Citarasu, T.; Alfred Dhas, K.; Velmurugan, S.; Thanga Viji, V.; Kumaran, T.; Michael Babu, M. and Selvaraj, T. (2011): Isolation of Aeromonas hydrophila from infected ornamental fish hatchery during massive disease outbreak. International Journal of Current Research.Vol.2, Issue, 1, pp. 037-041.

Dias, C.; Mota, V.; Murcia, A. and Saavedra, M.J. (2012): Antimicrobial resistance patterns of Aeromonas Spp. isolated from ornamental fish. J. Aquaculture research and development.3 (3):1-4.

Dixon, B.K.; Yarnashita, J. and Evelyn, F. (1990): Antibiotic resistance of Aeromonas spp. isolated from tropical fish imported from Singapore. Journal of Aquatic Animal Health 2: 295-297.

Elkamel, A.A. and Thune, R.L. (2003): Invasion and replication of Photobacterium damselae sub species piscicida in fish cell lines. J. Aquatic Animal Health, 15: 167-174.

Fayed, A.A.; Khater, A.A. and Abboud, O.A. (1997): Pseudomonas septicemia encopuntered in some ornamental fish. Alex. J. Vet. Science.13 (2): 93-100.

Garrity, G.M. (2001): Bergyy's manual systematic bacteriology. New York:Springer-Verlag.

Hettiarachchi, D.C. and Cheong, C.H. (1994): Some characteristics of Aeromonas hydrophila and Vibrio species isolated from bacterial disease outbreaks in ornamental fish culture in Srilanka. J. Natn. Sci. Coun. Srilanka. 2213: 261-269.

Innes, W.T. (1966): Exotic aquarium fish. $19^{\text {th }} \mathrm{Ed}$ Aquarium in Carparated. New Jersey.

Iqbal, MM.; Tajima, K. and Ezura, Y. (1999): Pathogenicity of Motile Aeromonas Species Isolated from Fishes with Epizootic Ulcerative Syndrome (EUS) in Southeast Asian Countries. Bull Fac Fish Hokkaido Univ. 50 (2), 93-100.

Kaser, M.; Bergeron, J.K.; Mays, A. and Aiello, S.E. (1991): The Merck Veterinary Manual. A handbook of diagnosis, therapy and disease prevention and Control for the veterinarian. 7th ed. Merck \& Co., New Jersey.

Khater, A.A.; Abboud, O.A. and Faed, A.A. (1997): Motile aeromonas septicaemia and other aeromonad infection encountered in coloured fish. Alex. J. Vet. Science.13 (2): 75-84.

Mastan, S.A. (2013): Pseudomonas septicemia in Labeo rohita (HAM) and Cyprinus carpio (LINN) in Andhra Pradesh- natural occurrence and artificial challenge. International Journal of Pharmacy and Pharmaceutical Sciences.5 (2): 564-568.

Marzouk, M.S.M.; Essa., M.A.A.; El-seedy, F.R.; Kenawy, A.M. and Abd El-Gawad, D.M. (2009): Epizootiological and Histopathological Studies on Mycobacteriosis in Some Ornamental Fishes. Global Veterinaria 3 (2): 137-143.

Melba, G.B.; McGladdery, S.E.; East, I. and Subasinghe, R.P. (2001): Asia Diagnostic Guide to Aquatic Animal Diseases. FAO, Fisheries technical Paper 402/2.

Musa, N.; Wei, SL.; Shaharom, F. and Wee, W. (2008): Surveillance of bacteria species in diseased freshwater ornamental fish from 
aquarium shop. World Appl. Sci. J. 3: 903-905.

Novick, R.P. (1981): The development and spread of antibiotic resistant bacteria as a consequence of feeding antibiotics to livestock. Ann. N.Y. Acad. Sci. 368: 23-59.

Palmeiro, B. and Roberts, H. (2009): Bacterial disease in fish. In: Mayer J, editor. Clinical Veterinary Advisor: Exotic Medicine. Elsevier; 2009, in press.

Rowe-Magnus, DA.; Guerout, AM. and Mazel, D. (2002): Bacterial resistance evolution by recruitment of super-integron gene cassettes. Mol Microbiol 43: 1657-1669.

Saavedra, M.J.; Novais, S.G.; Alves, A.; Marta, P.R.; Correia, T.A. and Murcia, A.M. (2004): Resistance to $\beta$ lactam antibiotics in $A$. hydrophila isolated from rainbow trout (Oncorhynchus mykiss) Int. Microbial, 7: 207- 211.

Schmidt, AS.; Bruun, MS.; Dalsgaard, I.; Pedersen, $K$. and Larsen, JL. (2000): Occurrence of antimicrobial resistance in fish-pathogenic and environmental bacteria associated with four Danish rainbow trout farms. Appl Environ Microbiol. 66: 4908-4915.

Shotts, E.B.; Kleckner, A.L.; Gratzek, J.B. and Blue, J.L. (1976): Bacterial flora of aquarium fishes and their shipping waters imported from Southeast Asia. Journal of the fisheries Research Board of Canada 33: 732-735.

Siegel, S.L.; Lewis, T.L.; Tripathi, N.K.; Burnley, V.V. and Latimer, K.S. (2004): Ulcerative bacterial dermatitis of koi (Cyprinus carpio) and ornanmental goldfish (Carassius auratus) [online]. Available from: http://www.vet.uga edu/vpp/undergrad/sieqel/ (Accssed 16 June 2004).

Wretlind, B.; Heden, L. and Wadstrom, T. (1973): Formation of extracellular haemolysin by Aeromonas hydrophila in relation to protease and staphylolytic enzyme. Journal of General Microbiology, 78: 57-65.

Yanong, R.P.E. (2006): Use of antibiotics in ornamental fish aquaculture. A series from the Department of Fisheries and Aquatic Sciences, Florida Cooperative Extension Service, IFAS extension, University of Florida. Circular 84.

\title{
دراسة عن بعض أنواع البكتيريا الهوائية فى أسماك الزينة \\ آية جلال سعد/لدين ، محمد رواى \\ Email: aya9galal@gmail.com
}

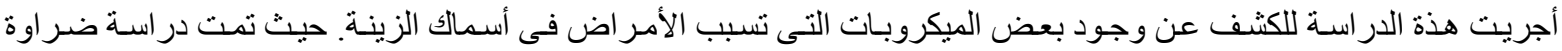

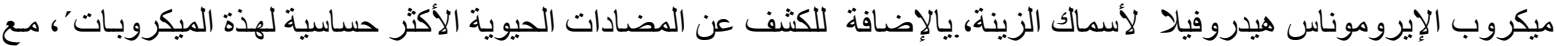

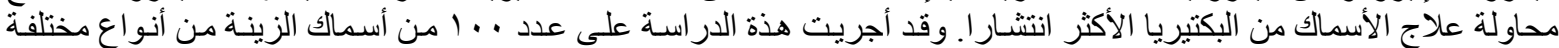

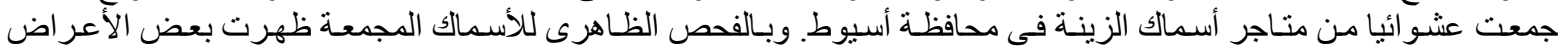

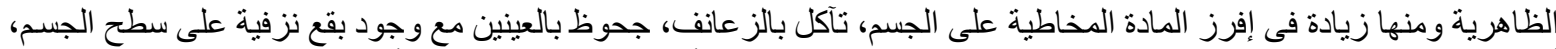

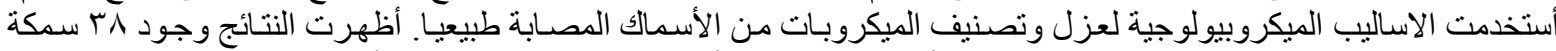

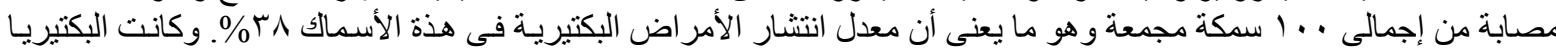

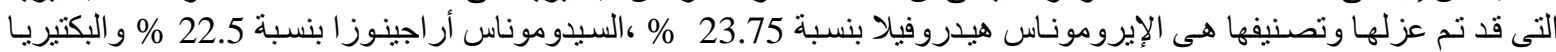

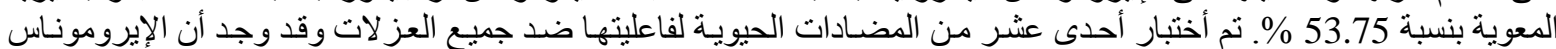

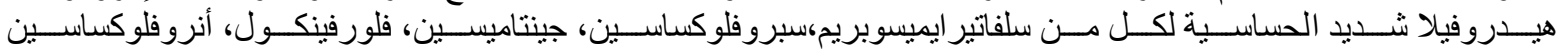

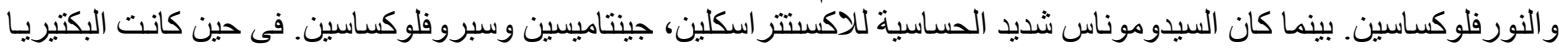

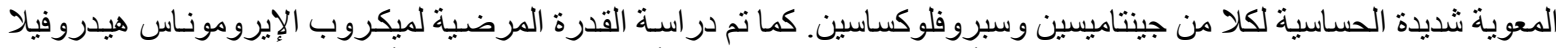

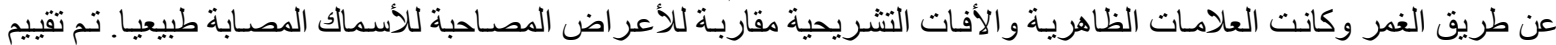

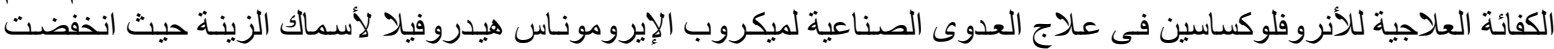

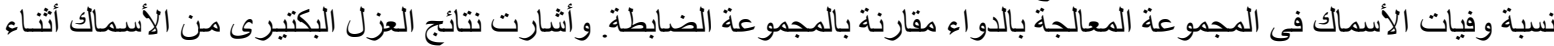

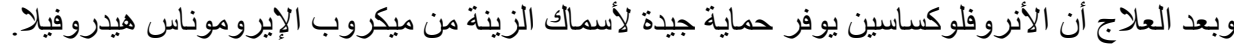

